\title{
Self-emulsifying formulation of Spinacia oleracea reduces the dose and escalates bioavailability of bioactive compounds to accelerate fracture repair in rats
}

Ritu Trivedi ${ }^{*}$, Sulekha Adhikary ${ }^{1}$, Priyanka Kothari ${ }^{1}$, Naseer Ahmad ${ }^{1}$, Naresh Mittapelly², Gitu Pandey ${ }^{2}$, Mahendra Shukla ${ }^{3}$, Sudhir Kumarr ${ }^{4}$ Kapil Dev ${ }^{4}$, Dharmendra Choudhary', Rakesh Maurya ${ }^{4}$, Jawahar Lal ${ }^{3}$ and Prabhat Ranjan Mishra ${ }^{2^{*}}$

\begin{abstract}
Background: Spinach (Spinacia oleracea) is a rich source of flavonoids and therefore widely used therapeutically as an antioxidant agent in traditional medicine. The present study was undertaken to study the bone regenerating property of dried Spinacia oleracea extract (DSE) and self-emulsifying formulation of the extract (FDSE) on drill-hole model of fracture repair in rats.

Methods: $0.8 \mathrm{~mm}$ hole was drilled in the diaphyseal region of femur in adult SD rats. DSE and formulated extract (FDSE) was administered orally and fractured femur was collected after treatment regimen. Micro-CT, transcriptional analysis and measurement of calcein intensity of callus formed at the injured site was performed to study the efficacy of the extract and formulation on bone regeneration. Further, compounds from extract were assessed for in-vitro osteoblast activity.

Results: Micro-architecture of the regenerated bone at injured site exhibited 26\% ( $p<0.001)$ and 35\% $(p<0.01)$ increased BV/TV (bone volume /tissue volume) and Tb.N. (trabecular number) for DSE (500 mg. $\mathrm{kg}^{-1}$ ). Further, FDSE exhibited similar augmentation in BV/TV $(p<0.01)$ and Tb. $N(p<0.01)$ parameters at dose of $250 \mathrm{mg} \cdot \mathrm{kg}^{-1}$. Analogous results were obtained from transcriptional analysis and calcein intensity at the fractured site. 3-O-Methylpatuletin, one of the compound isolated from the extract stimulated the differentiation and mineralization of primary osteoblast and depicted concentration dependent antagonizing effect of $\mathrm{H}_{2} \mathrm{O}_{2}$ in osteoblast apparently, minimizing ROS generation thus affectivity in fracture repair.
\end{abstract}

Conclusions: The present study showed that bone regenerating property of spinach was augmented by formulating extract to deliverable form and can be further studied to develop as therapeutic agent for fracture repair.

Keywords: Spinacia oleracea, Spinach, Fracture healing, Micro-CT, Bone regeneration

\footnotetext{
*Correspondence: ritu_trivedi@cdri.res.in; ritu_pgi@yahoo.com;

prabhat_mishra@cdri.res.in; mishrapr@hotmail.com

'Division of Endocrinology, CSIR-Central Drug Research Institute, B.S. 10/1,

Sector 10, Jankipuram Extension, Sitapur Road, Lucknow, Uttar Pradesh

226031, India

2Division of Pharmaceutics, CSIR-Central Drug Research Institute, B.S. 10/1,

Sector 10, Jankipuram Extension, Sitapur Road, Lucknow, Uttar Pradesh

226031, India

Full list of author information is available at the end of the article
}

\section{Springer Open}

(c) The Author(s). 2020 Open Access This article is licensed under a Creative Commons Attribution 4.0 International License, which permits use, sharing, adaptation, distribution and reproduction in any medium or format, as long as you give appropriate credit to the original author(s) and the source, provide a link to the Creative Commons licence, and indicate if changes were made. The images or other third party material in this article are included in the article's Creative Commons licence, unless indicated otherwise in a credit line to the material. If material is not included in the article's Creative Commons licence and your intended use is not permitted by statutory regulation or exceeds the permitted use, you will need to obtain permission directly from the copyright holder. To view a copy of this licence, visit http://creativecommons.org/licenses/by/4.0/. 


\section{Introduction}

S. oleracea L. commonly known as Spinach, is an edible flowering plant in the family of Amaranthaceae. It is an erect herb about $30-60 \mathrm{~cm}$ height, native to South-West Asia and cultivated throughout world as vegetables. Spinach is recommended as the best source of iron, vitamins and minerals. It is a well-known source of bioactive phytochemicals and nutrients such as ascorbate, carotenoids, tocopherols, phenolics, flavonoids, folate and minerals [1]. Kaempferol, myricetin, quercetin, apigenin and luteolin are some of the constituents in spinach leaves extract. Spinach extract has numerous beneficial effects such as anti-oxidative, hepato-protective [2], antiinflammatory [3] and anti-cancer effect [4]. Our previous studies on ethanolic extract of Spinacia oleracea exhibits bone restoration in ovariectomy induced bone loss model of osteoporosis in rats and the effect was comparable to estrogen [5]. Additionally, recent studies from our group indicated that spinach alleviates monosodium iodoacetate (MIA) induced osteoarthritis in rats by reducing inflammation, articular and sub-chondral bone loss. Moreover, bioactive constituents characterized from the extract exhibit significant chondrocyte protective effects in articular chondrocytes apparently preventing cartilage damage in MIA induced osteoarthritis [6]. Considering the beneficial effects of spinach on bone and cartilage, we have a growing interest in its potential use for the treatment of fracture repair where both cartilage cells and osteoblast cells play important role to heal the defect region [7]. Moreover, identification and characterization of bioactive components from the extract can help further in its development as an effective rapid fracture healing molecule.

Flavonoids may occur either in the form of glycosides (hydrophilic in nature) or aglycones (lipophilic in nature). The intestinal microflora has major role deciding absorption of either glycosides or aglycones [8]. The microflora converts glycosides into aglycones and thus facilitates absorption. Nevertheless, there are certain cases where glycosides may not be substrates for the enzymes or microflora, thus they are moved towards colon where they get hydrolyzed by bacteria but it results in low absorption since absorption in the colon is very less [9]. The main reason for low bioavailability in humans is Phase II metabolism [10] along with other physicochemical properties. In addition, there are several flavonoids that undergo conjugation reactions like glucuronidation, methylation and sulfation in small intestine and liver. Except few conjugated flavonoids, many of their metabolites exhibit low bioavailability and bioactivity. It is also reported that several flavonoids show bioactivity in vitro but their bioactivity in vivo is jeopardized due to extensive metabolism and low bioavailability $[11,12]$. Due to these limitations bioavailability enhancement becomes a major issue for the oral delivery of flavonoids. Therefore it becomes mandatory to develop a formulation that could improve the metabolic stability and enhance the absorption of flavonoids to achieve maximum therapeutic benefits. Presence or absence of food and age also affects the level of microflora and rate of metabolism that pose direct or indirect effects on absorption. To establish availability of potential biomarkers vis-à-vis its efficacy and to maximize the in vivo efficacy of the potential molecule, it needs to have good absorption and distribution in various body tissues; therefore it was in our interest to develop a suitable delivery system in the form of self -emulsifying formulation.

Although there are numerous ways to increase bioavailability of flavonoids, self-emulsifying formulations is one of them. Self-emulsifying formulations are based on nanoemulsion pre-concentrate and are comprised of natural or synthetic oils, solid or liquid surfactants or, alternatively, one or more hydrophilic solvents and co-solvents/surfactants and thus they are robust in terms of dilution. SEDDS (self-emulsifying drug delivery system) formulation used in this study are isotropic mixtures of oils, solid or liquid surfactants and one or more hydrophilic solvents and surfactants/co-solvents and are considered to be interesting approach for enhancing the oral bioavailability of drugs [13]. These systems are capable of producing water in oil nano-emulsions or micro emulsions upon contact with the digestive fluids under the influence of mild agitation caused by the gastrointestinal motility. The resultant fine droplets provide a high surface area for drug release and absorption particularly for lymphatic transport and avoid hepatic first pass metabolism [14]. Further, the absorption of drugs can be also enhanced by altering the membrane fluidity, opening of tight junction for para-cellular transport, and inhibition of efflux transporters such as P-glycoprotein [15].

Fracture healing is a complex proliferative and differentiative physiological process highly regulated by cellular, and molecular/genetic factors [7]. Molecular mechanisms known to regulate skeletal tissue formation during embryological development are repeated during the fracture healing process $[16,17]$. The signaling molecules involved in fracture healing include pro-inflammatory cytokines which interact with several cell types, including bone and cartilage forming primary cells, thus initializing a cascade of event resulting in callus formation at the fracture injury site $[18,19]$. Presently, there is no approved orally available treatment for fracture healing. Parathyroid hormone (PTH), anti-sclerostin antibodies and BMPs have shown promising results in this direction but further research is required before clinical use as a pharmacological agent [20]. Calcium and vitamin D are administered to reduce the risk of vertebral fracture and prevent hypocalcaemia [21, 22].

Spinacia oleracea owing to its anti-inflammatory and osteogenic property along with the capability to modulate osteoprogenitor cells in bone marrow could accelerate the bone repair process at the fracture site. 
Additionally, it was equally important to formulate the extract with the perspective to enhance its bioavailability and at the same time study the osteogenic property of the characterized compounds isolated from the extract. Therefore, in our study we compared the effect of dried spinach extract (DSE) with formulated DSE (FDSE) on fracture healing model and examined the osteogenic efficacy of isolated compounds.

\section{Materials and methods Chemicals}

Cell culture media and supplements such as Modified Eagle Medium, Fetal bovine serum (FBS), 3-(4,5-dimethylthiazol-2-yl)-2,5-diphenyltetrazolium bromide (MTT), $2^{\prime}, 7^{\prime}$-Dichlorofluorescindiacetate (DCFDA) were purchased from Sigma-Aldrich (St. Louis, MO, USA). Complementary DNA (cDNA) synthesis kit was purchased from Thermo Fisher Scientific (Waltham, Massachusetts, USA) and SYBR Green kit was obtained from Genetix (New Delhi, India).

\section{Plant material collection and extraction}

Spinacia oleracea Linn. (CDRI plant code No. 2492) was purchased from local market of Lucknow-226,021, located at $26.8^{\circ} \mathrm{N} 80.9^{\circ} \mathrm{E}$ in U.P. India. The Spinacia oleracea leaves were dried in the shade in a well-ventilated enclosure. The dried leaves were powdered $(3 \mathrm{~kg})$ and placed in glass percolator with ethanol $(5 \mathrm{~L})$ and are allowed to stand at room temperature for $24 \mathrm{~h}$. The percolate was collected. This process of extraction was repeated for four times. The combined extract was filtered, concentrated under reduced pressure at $45^{\circ} \mathrm{C}$, weight of extract obtained $540 \mathrm{~g}(18 \%, 2492-\mathrm{C} 003)$. This formed the 'stock' of dried Spinacia oleracea extract (DSE) leaves, stored at $4{ }^{\circ} \mathrm{C}$.

\section{Fractionation of extract (DSE)}

Ethanolic extract $(270 \mathrm{~g})$ was triturated with ethyl acetate $(500 \mathrm{ml} \mathrm{X} \mathrm{8)}$. The ethyl acetate soluble fraction was then concentrated under the reduced pressure at $45^{\circ} \mathrm{C}$, weight of ethyl acetate fraction obtained was $34 \mathrm{~g}$ (12.59\%, with respect to extract, F004). The insoluble fraction was suspended in distilled water $(1000 \mathrm{ml})$ and extracted with n-butanol ( $800 \mathrm{ml} \mathrm{X} \mathrm{7)}$. The combined $\mathrm{n}$ butanol soluble fraction was concentrated under the reduced pressure at $45^{\circ} \mathrm{C}$, weight of n-butanol soluble fraction $112 \mathrm{~g}$ (41.48\%, with respect to extract, F005). The aqueous fraction obtained was $115 \mathrm{~g}$ (42.59\% with respect to extract, F006) (Fig. 1a).

Isolation of active marker compounds from $n$-butanol soluble fraction (F005) of Spinacia oleracea leaves The $\mathrm{n}-\mathrm{BuOH}$ soluble fraction $(95.0 \mathrm{~g}$, F005) was subjected to silica gel column chromatography (100-200 mesh), with the ethyl acetate and gradient of EtOAc-MeOH (95: 5, 90:10, 75:25, 65:35, 50:50 and $\mathrm{MeOH}$ ) as eluent. Six fractions (F1-F6) were collected according to TLC analysis. Fraction F2 was purified on silica gel column chromatography eluted with $\mathrm{CHCl}_{3}-\mathrm{MeOH}$ (97:03) afforded one compounds $(50 \mathrm{mg}, 0.0525 \%$ with respect to extract, K007), further elution with $\mathrm{CHCl}_{3}-\mathrm{MeOH}$ (95:05) afforded (20 mg, 0.021\% with respect to extract, K008). These compounds were characterized with the help of detailed spectroscopic studies (Supplementary data).

\section{HPLC analysis of extract, fraction and pure compounds}

HPLC analysis of $S$. oleracea extract, $n$-butanol fraction and isolated pure compounds was carried out on Shimadzu HPLC system (LC solutions ver 1.25) using mobile phase with composition: $0.2 \% \mathrm{v} / \mathrm{v}$ phosphoric acid in water: methanol in a ratio of 48:54. The compounds were detected at $365 \mathrm{~nm}$ with flow rate at $1.0 \mathrm{ml} / \mathrm{min}$. HPLC data of extract and compound have already been reported in our previous paper [6].

\section{Preparation of self emulsifying drug delivery system (SEDDS) \\ Preparation of blank SEDDS formulation}

Accurately weighed quantities of oil (oleic acid) $55 \% \mathrm{w} /$ $\mathrm{w}$, surfactant (polysorbate 80 ) $20 \% \mathrm{w} / \mathrm{w}$, co-surfactant $20 \% \mathrm{w} / \mathrm{w}$ (propylene glycol) and solubilizer (PEG 600) $5 \% \mathrm{w} / \mathrm{w}$ were placed in a beaker and mixed thoroughly using magnetic stirrer to obtain a clear yellow solution.

\section{Preparation of spinach extracts containing SEDDS formulation}

The formulation was prepared by dissolving weighed quantity of Spinacia oleracea extract $(5 \% \mathrm{~W} / \mathrm{W})$ in the mixture of oleic acid $(55 \% \mathrm{~W} / \mathrm{W})$, surfactant tween 80 $(20 \% \mathrm{~W} / \mathrm{W})$, co-surfactant propylene glycol $(20 \% \mathrm{~W} / \mathrm{W})$ and solubilizer PEG $200(5 \% \mathrm{~W} / \mathrm{W})$. This mixture was kept on stirring at $70{ }^{\circ} \mathrm{C}$, overnight to obtain a clear and transparent preparation. This formulation was stored at ambient temperature for further use. The formulation (FDSE) was stored in a glass container at room temperature for further use. SEDDS formulation was characterized for particle size distribution, drug precipitation after dilution (1 in 10).

\section{Animals and experimental procedures}

All animal experiments were conducted in accordance with current legislation on animal experiments approved by Institutional Animal Ethical Committee (IAEC) (IAEC/2014/38] at C.D.R.I. Adult female Sprague Dawley rats (weighing aprox.180-200 g) were taken for the study ( $n=10 /$ group). A drill-hole injury was created by inserting a drill bit of $0.8 \mathrm{~mm}$ diameter in the anterior diaphysis portion of one femur [23, 24]. Briefly, under 


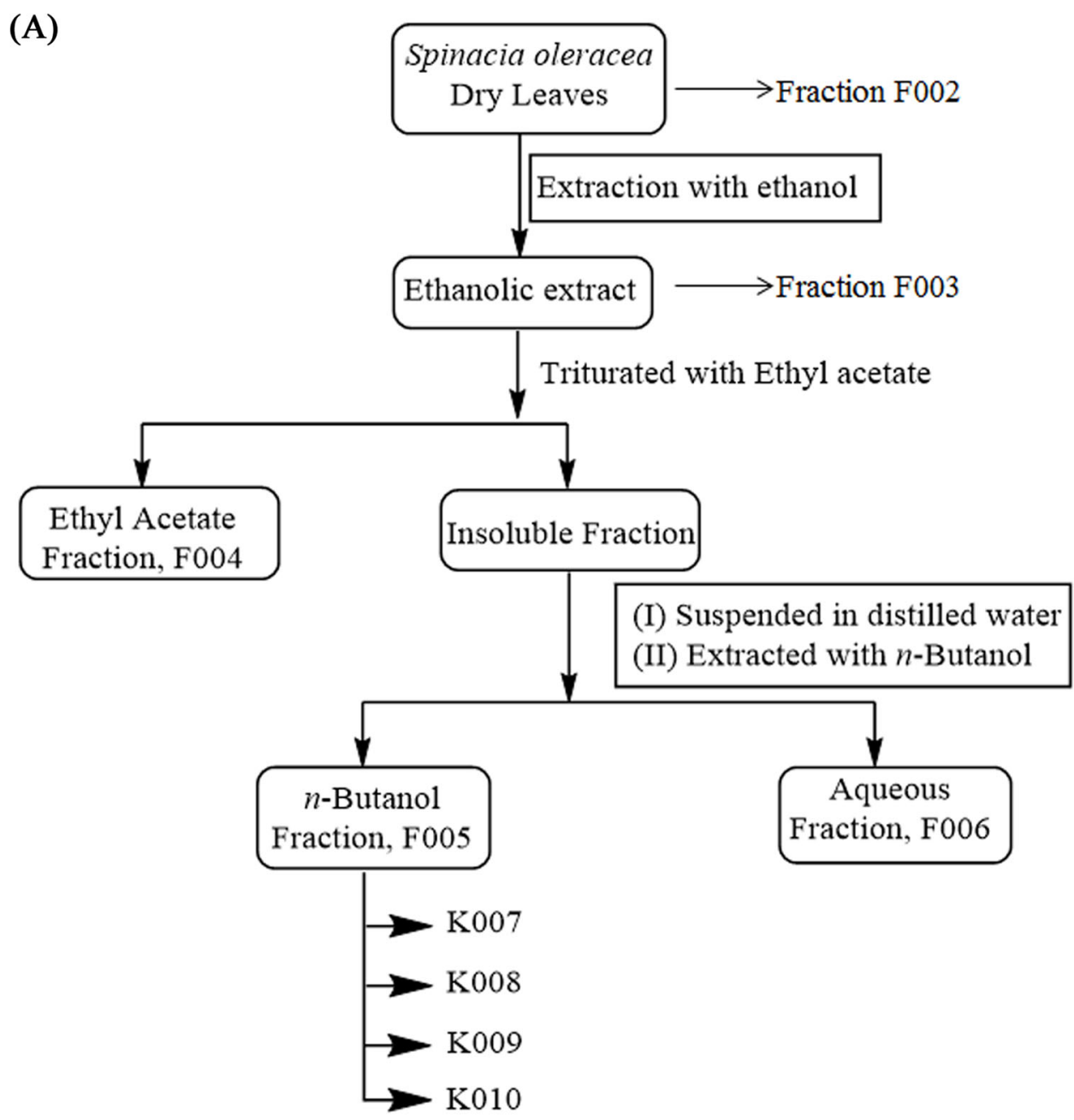

(B)

Size Distribution Intensity

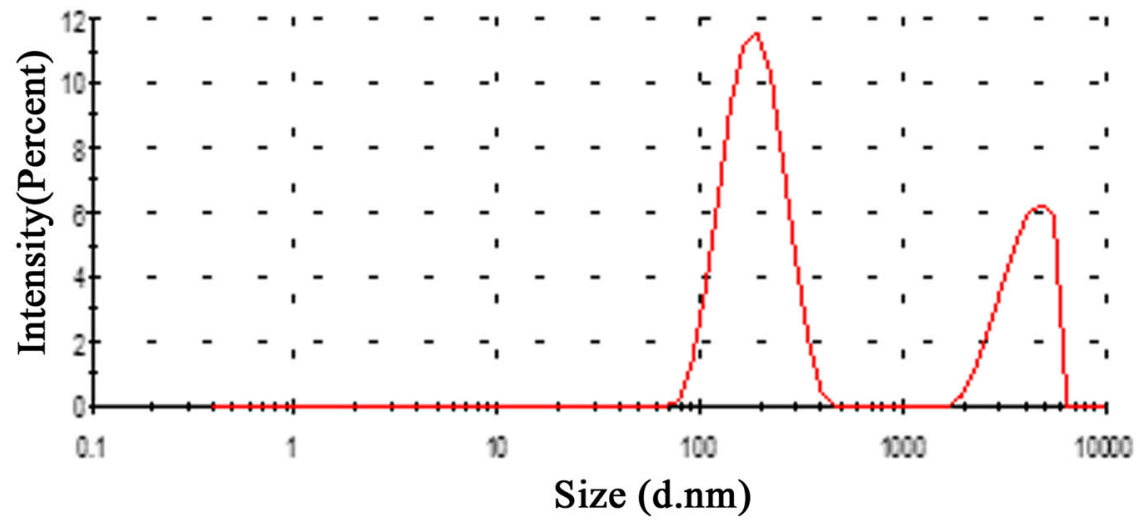

Fig. 1 a Fractionation procedure of dried leaves extract of Spinacia oleracea. b Particle size distribution of SEEDS formulation after diluting 1 in 10 
anesthesia the front skin of the mid-portion of the femur were cut straight and longitudinally $2 \mathrm{~cm}$ above the knee joint. The femoral bone surface was exposed by splitting the muscle and stripping the periosteum. A drill-hole injury was created with a drill bit. The treatment was started after 1 day of drill-hole injury and continued for 2 weeks. Plant extract (DSE) at various doses and formulation (FDSE) were administered orally by gavage. PTH was taken as a standard positive control as it enhances fracture healing [24]. Forty eight hours before autopsy, all animals were given a fluorochrome, calcein (20 $\mathrm{mg} . \mathrm{kg}^{-1}$ body weight) dissolved in normal saline via intraperitoneal route. At the end of the treatment regimen animals were autopsied and fractured femur collected for micro-CT and transcription analysis. For calcein binding measurement, fixed bones were embedded in an acrylic material and $50 \mu \mathrm{m}$ sections were made using Isomet Bone cutter (Agra, UP, India). Photographs of calcein labeling at fractured site was taken by confocal microscope (Carl Zeiss LSM 510 Meta) aided with appropriate filters and intensity calculated using Carl Zeiss AM4.2 image analysis software [5].

\section{Assessment of trabecular micro-architecture by micro-CT}

Micro-CT of excised bones was carried out using a Sky Scan 1076 micro-CT scanner (Sky Scan, Aartselaar, Belgium). Scanning was done at $70 \mathrm{kV}, 142 \mathrm{~mA}$ using a $1 \mathrm{~mm}$ aluminum filter at a resolution of $18 \mu \mathrm{m} /$ pixel. Cross sectional reconstruction was made using Nrecon software based on modified feldkamp algorithm. Fractured region of femur were analyzed via CT analyzer (CTAn; Sky Scan) software [5].

\section{Quantitative real time PCR analysis of various bone-specific genes}

Excised bones devoid of bone marrow were ground into powder in liquid nitrogen. Total RNA was isolated by Trizol method (Invitrogen). Complementary DNA was synthesized and quantitative realtime PCR was performed as in previous published protocol [5] (Table 1).

\section{In vitro osteogenic activity in primary osteoblast culture Primary osteoblast culture}

Rat calvarial osteoblast (RCO) cells were obtained following previously published protocol. Briefly, calvarium from ten to twelve 1-2 day old rat pups were harvested, cleaned, and subjected to five sequential enzymatic digestions $(0.1 \%$ dispase and $0.1 \%$ collagenase I) of $10-15$ min each. Cells were collected, re-suspended and cultured in $\alpha$-MEM containing 10\% fetal bovine serum (FBS) and 1\% penicillin/streptomycin (osteoblast proliferation medium). Calvarial osteoblast cells were allowed to reach confluency of $80 \%$ for further experiments [25].

\section{Alkaline phosphatase (ALP) activity and MTT assay}

Primary osteoblast cells were seeded in 96 well plates in osteoblast proliferation medium for $24 \mathrm{~h}$. On reaching confluency cells were treated with different concentrations of the test compound or vehicle for $48 \mathrm{~h}$ in growth medium supplemented with $10 \mathrm{mM} \beta$-glycerophosphate and $50 \mu \mathrm{g} \cdot \mathrm{ml}^{-1}$ ascorbic acid (osteoblast differentiation medium). At the end of experiment ALP assay plates were kept at $-80^{\circ} \mathrm{C}$ for overnight then incubated at $37^{\circ} \mathrm{C}$ to rupture the cells. ALP activity was measured using p-nitrophenyl phosphate (pNPP) as substrate and absorbance was read at $405 \mathrm{~nm}$. After $48 \mathrm{~h}, 10 \mu \mathrm{L}$ of MTT $(5 \mathrm{mg} / \mathrm{ml})$ solution was added in each well of MTT assay plates and kept at $37^{\circ} \mathrm{C}$ for $4 \mathrm{~h}$, then media was discarded followed by addition of $100 \mu \mathrm{l}$ DMSO into each well. Absorbance was taken at $570 \mathrm{~nm}$ [25].

\section{Mineralization assay}

Cells were seeded in 12 well plates for mineralization assay. After initial proliferation for $48 \mathrm{~h}$, cells were cultured for 21 days in differentiation medium supplemented with test compounds and vehicle to facilitate calcium nodule formation. At the end of the treatment period cells were fixed in $4 \%$ formaldehyde and stained with $40 \mathrm{mM}$ (pH 4.5) Alizarin. Quantification was facilitated with ammonium hydroxide and O. D taken at $405 \mathrm{~nm}$ [25].

\section{Quantitative real-time polymerase chain reaction (qPCR)}

Cells were treated with different concentrations of active compound for $72 \mathrm{~h}$. RNA was extracted and quantitative real time PCR reaction performed for determination of the relative expression of osteogenic genes RUNX2, BMP-2, COL-1 compared to untreated cells [25].

\section{ROS generation}

DCFDA is a non-fluorescent dye which fluoresces on binding to ROS cleaving to form DCF (fluorophore). Fluorescence was measured by fluorimetry at excitation $480 \mathrm{~nm}$ and emission $535 \mathrm{~nm}$. Cells were pre-treated for $24 \mathrm{~h}$ with compound at concentrations $100 \mu \mathrm{M}, 1 \mu \mathrm{M}, 10 \mathrm{nM}, 100 \mathrm{pM}$ and $1 \mathrm{pM}$ and incubated with positive control $\mathrm{H}_{2} \mathrm{O}_{2}(0.03 \%)$ for $4 \mathrm{~h}$ to generate ROS. Cells were treated with DCFDA $\left(10 \mu \mathrm{g} \cdot \mathrm{ml}^{-1}\right)$ for $30-45 \mathrm{~min}$ prior to termination of the experiment. NAC ( $\mathrm{N}$-acetyl-L-cysteine) $10 \mathrm{mM}$ was used as positive to antagonize ROS generation [26].

\section{Pharmacokinetic study \\ Oral bioavailability}

Animals were fasted overnight (12-16 h) and randomly divided into two groups ( $n=6$ /group) First group of rat received a single oral dose of DSE at $500 \mathrm{mg} \cdot \mathrm{kg}^{-1}$. The second group of rats received a single oral dose of formulated extract (FDSE) at dose of $250 \mathrm{mg} \cdot \mathrm{kg}^{-1}$.The blood samples were collected at 0.5, 1, 2, 4, 8, 12 and 24 
Table 1 Primer sequence of various genes used for $q P C R$

\begin{tabular}{llll}
\hline Gene Symbol & Gene Name & Primer Sequence & Accession Number \\
\hline RUNX2 & Runt-related transcription factor2 & F-CCACAGAGCTATTAAAGTGACAG & NM_053470 \\
BMP2 & Rone morphogenetic protein2 & F-CCCCTATATGCTCGACCTGT & NM_017178.1 \\
OCN & R-AAAGTTCCTCGATGGCTTCTT & NM-013414 \\
COL1 & F-ATAGACTCCGGCGCTACCTC & NM_053304 \\
BMP4 & Typel Collagen & R-CCAGGGGATCTGGGTAGG & F-CATGTCAGCTTGTGGACCT \\
& Bone morphogenetic protein4 & R-GCAGCTGACTTCAGGGATG & NM_012827.2 \\
\hline
\end{tabular}

h. post dose and serum samples were stored at $-80{ }^{\circ} \mathrm{C}$ until analysis. Pharmacokinetic parameters like area under the curve (AUC), peak serum concentration $\left(\mathrm{C}_{\max }\right)$, time to $\mathrm{C}_{\max }\left(\mathrm{t}_{\max }\right)$, total clearance $(\mathrm{Cl})$ and mean residence time (MRT), steady state volume distribution $\left(\mathrm{V}_{\mathrm{ss}}\right)$ were determined by drug concentration versus time curve [27].

\section{Analysis of biomarkers in serum samples}

A Shimadzu UFLC pump (LC-20 AD) with online degasser (DGU-20A3), an auto-sampler (SIL-HTc) with a temperature-controlled peltier-tray and a triple quadrupole API 4000 Q trap mass spectrometer (Applied Biosystems, Toronto, Canada) was used for analysis. Chromatographic separation was made on a Discovery HS C-18 column $(5 \mu \mathrm{m}, 100 \times 4.6 \mathrm{~mm}$ id) preceded with a guard column ( $5 \mu \mathrm{m}, 20 \times 4.0 \mathrm{~mm}$, id) packed with the same material with mobile phase $[0.2 \%$ formic acid in methanol: Milli $\mathrm{Q}$ water $(90: 10, \mathrm{v} / \mathrm{v})]$ pumped at a flow rate of $0.7 \mathrm{~mL} / \mathrm{min}$ under isocratic condition. The mobile phase was degassed by ultrasonication for $15 \mathrm{~min}$ before use. LC-MS/MS system was equilibrated for approximately $20 \mathrm{~min}$ before commencement of analysis. The analysis time was $3 \mathrm{~min}$ per sample. The mass spectral analysis was performed in multiple reaction monitoring mode (MRM) was used to monitor the transitions $\mathrm{m} / \mathrm{z} 345.0 \rightarrow \mathrm{m} / \mathrm{z} 330.1 \quad(\mathrm{~K} 007), \quad \mathrm{m} / \mathrm{z} 346.9 \rightarrow \mathrm{m} /$ z289.0(K008), m/z345.0 $\rightarrow$ m/z330.1 (K009), m/z346.9 $\rightarrow$ m/ $\mathrm{z} 289.0(\mathrm{~K} 010)$ and $\mathrm{m} / \mathrm{z} 180.1 \rightarrow \mathrm{m} / \mathrm{z} 138.2$ (phenacetin; internal standard) in positive ionization mode at $5500 \mathrm{~V}$. An aliquot $(50 \mu \mathrm{l})$ of the serum samples was hydrolyzed using $\beta$ glucuronidase and subjected to liquid-liquid extraction using tert-butyl methyl ether. Data acquisition and quantitation were performed using analyst software (version 1.4.2; $\mathrm{AB}$ Sciex, Toronto, Canada).

\section{Statistical analysis}

Data are expressed as Mean \pm SEM. The data obtained in experiments were subjected to one-way ANOVA followed by Newman-Keuls multiple comparison test of significance using Graph Pad Prism 5.0 software.

\section{Results}

Preparation of self-micro emulsifying drug delivery system (SEDDS)

Different blank SEDDS formulations were prepared by varying the ratio of oil to co-surfactant to increase the loading and decrease the precipitation of extract after dilution. The optimized formulation showed good stability against precipitation after dilution. The mean particle size of the formulation was found to be $253.4 \pm 1.485 \mathrm{~nm}$ with polydispersive index (PDI) $0.564 \pm 0.081$ (Fig. 1b).

\section{Effect of extract and formulation on in vivo fracture healing}

Bone micro-architecture parameters changes at fracture site Dried Spinacia oleracea extract (DSE) at dose of 500 mg. $\mathrm{kg}^{-1} \mathrm{dy}^{-1}$ exhibited enhanced bone regeneration at fracture site as compared to vehicle treated control (Fig. 2a,b). However, formulation of the extract (FDSE) resulted in lowering the effective dose to 250 mg.kg-1 $\mathrm{dy}^{-1}$ as evident from the micro-CT data (Fig. 2c). $\mathrm{BV} / \mathrm{TV}$ (bone volume/tissue volume) was increased by $\sim 26 \%(p<0.01)$ at $500 \mathrm{mg} \cdot \mathrm{kg}^{-1} \mathrm{dy}^{-1}$ of DSE compared to control group whereas; no significant effect was observed at the lower dose. Formulated extract (FDSE) resulted in $\sim 26 \% \quad(p<0.01)$ and $\sim 32.4 \% \quad(p<0.001)$ increase in BV/TV at 250 and $500 \mathrm{mg} \cdot \mathrm{kg}^{-1} \mathrm{dy}^{-1}$ dose compared to control. Dose of $250 \mathrm{mg} \cdot \mathrm{kg}^{-1} \mathrm{dy}^{-1}$ FDSE demonstrated a $41.71 \%(p<0.001)$ increment in BV/TV relative to extract at the same dose. Intermittent PTH given as a positive control displayed $47 \%(p<0.001)$ rise in $\mathrm{BV} / \mathrm{TV}$ and was non-significant when compared to FDSE. Similarly, Tb.N. (trabecular number) was increased by $\sim 35 \%(p<0.05)$ in $500 \mathrm{mg} \cdot \mathrm{kg}^{-1} \mathrm{dy}^{-1}$ dose both in DSE and FDSE and 38\% $(p<0.01)$ in PTH treated animals (Fig. 2d). No change was observed in Tb.N. at lower dose of DSE whereas, 33\% $(p<0.01)$ increment was observed in FDSE at $250 \mathrm{mg} \cdot \mathrm{kg}^{-1} \mathrm{dy}^{-1}$ dose. Findings from positively correlated parameters for improved bone micro-architecture were substantiated by data obtained from negatively linked parameters viz. Tb. Sp (trabecular separation) (defines the separation between the 

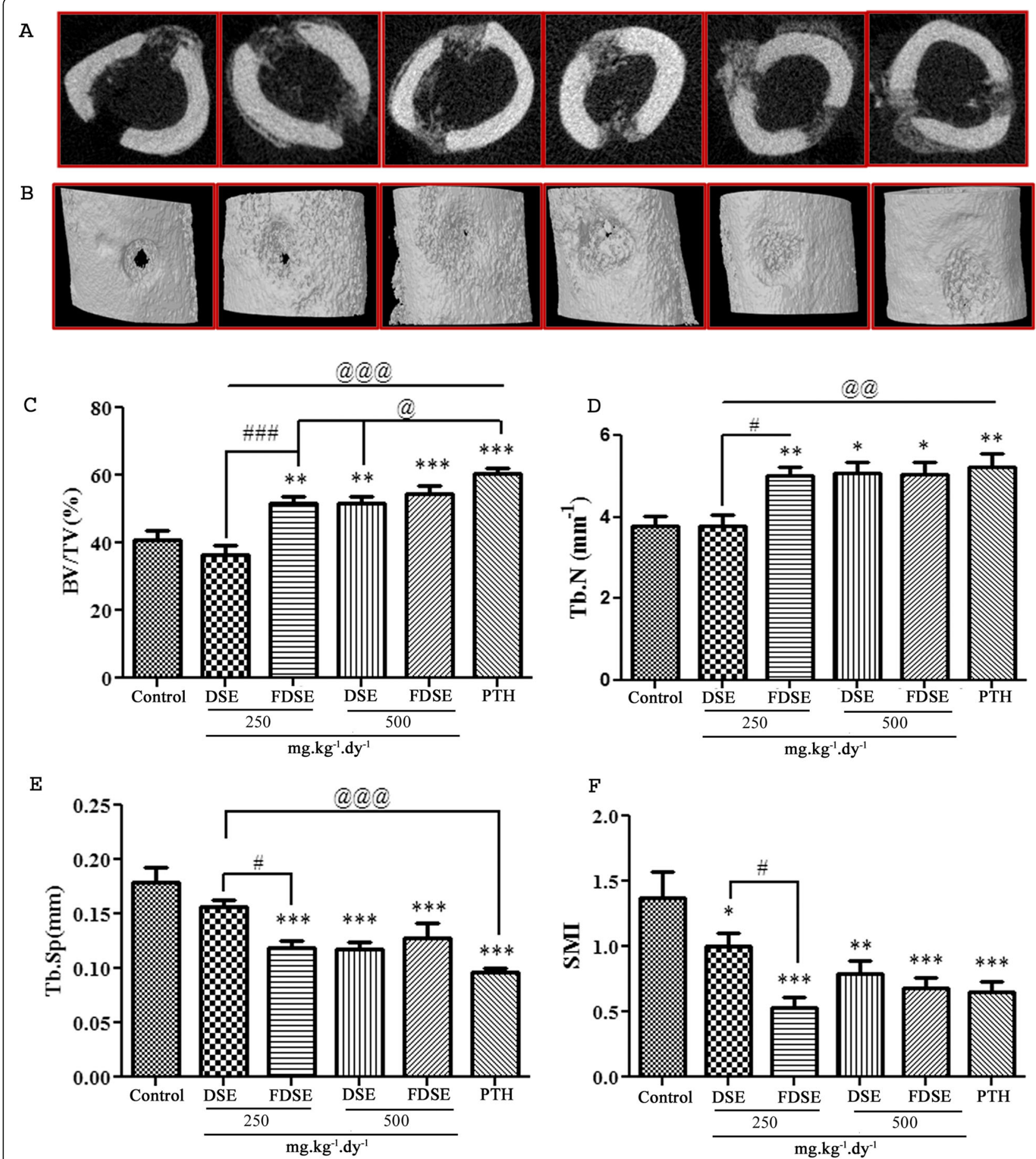

Fig. 2 DSE and FDSE improved micro-architectural parameters in the drill-hole site and accelerates bone regeneration at the fracture site. Representative 2D (a) and 3D (b) images generated by micro-CT showing bone healing at different doses. Micro-CT analysis showing (c) bone volume/tissue volume BV/TV; (d) trabecular number (Tb.N); (e) trabecular separation (Tb.Sp); (f) structure model index (SMI). All values are expressed as Mean \pm SEM $\left(n=10\right.$ rats/group). $p<0.05,{ }^{* *} p<0.01,{ }^{* * *} p<0.001$ compared with control. ${ }^{\#} p<0.05,{ }^{\# \#} p<0.01,{ }^{\# \# \#} p<0.001$ compared to formulated extract (FDSE) with corresponding dose of extract (DSE). ${ }^{@} p<0.05,{ }^{@} p<0.01, @ @ p<0.001$ compared to PTH

trabecular network) and SMI (structure model index) (indicator of the structure of trabeculae and high values demonstrates greater accumulation of micro-damage).
Tb. Sp was reduced by $34 \%(p<0.001)$ and $29 \%(p<$ $0.001)$ in $500 \mathrm{mg} \cdot \mathrm{kg}^{-1} \mathrm{dy}^{-1}$ dose of DSE and FDSE respectively. At $250 \mathrm{mg} \cdot \mathrm{kg}^{-1} \mathrm{dy}^{-1}$ dose $\mathrm{Tb}$. Sp was 


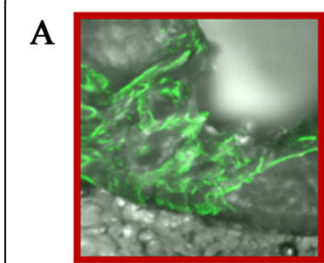

Control

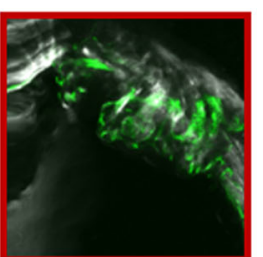

DSE

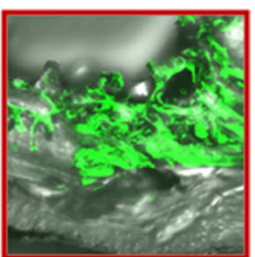

F DSE

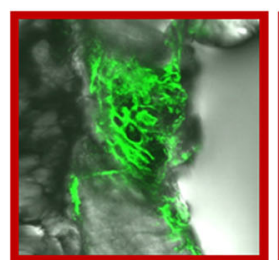

DSE

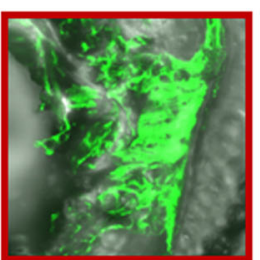

F DSE

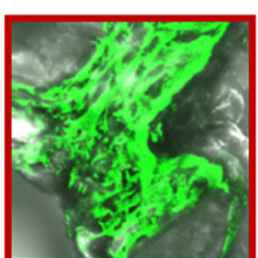

PTH

$250 \mathrm{mg} \cdot \mathrm{kg}^{-1} \mathrm{dy}^{-1}$

B

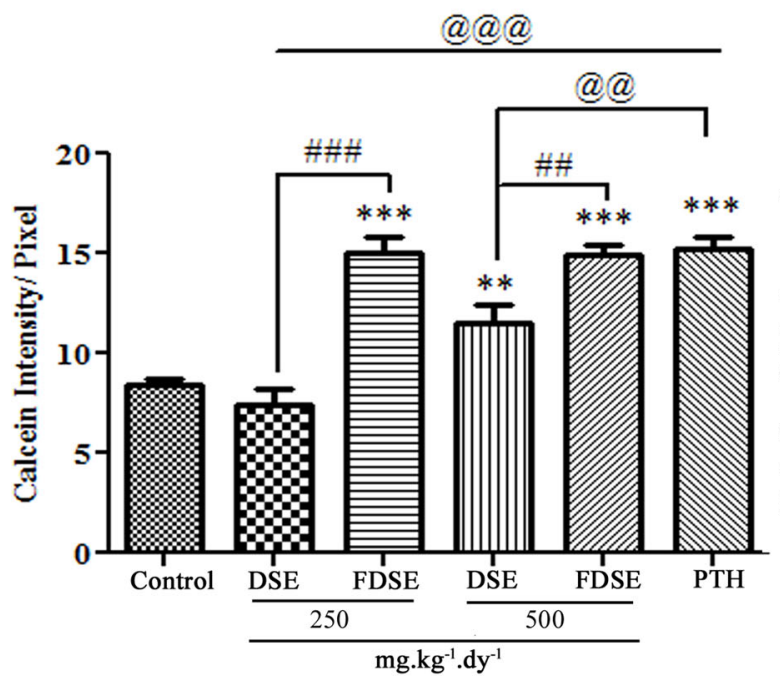

D

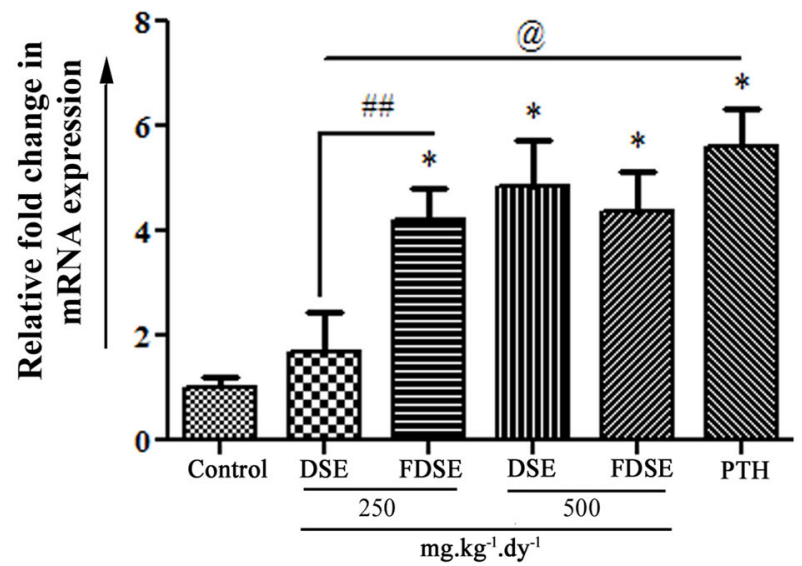

BMP-2

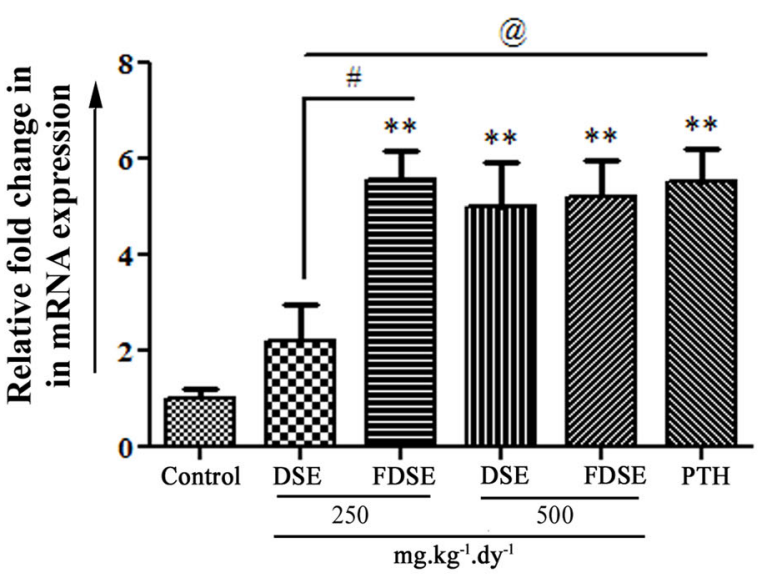

E

BMP-4

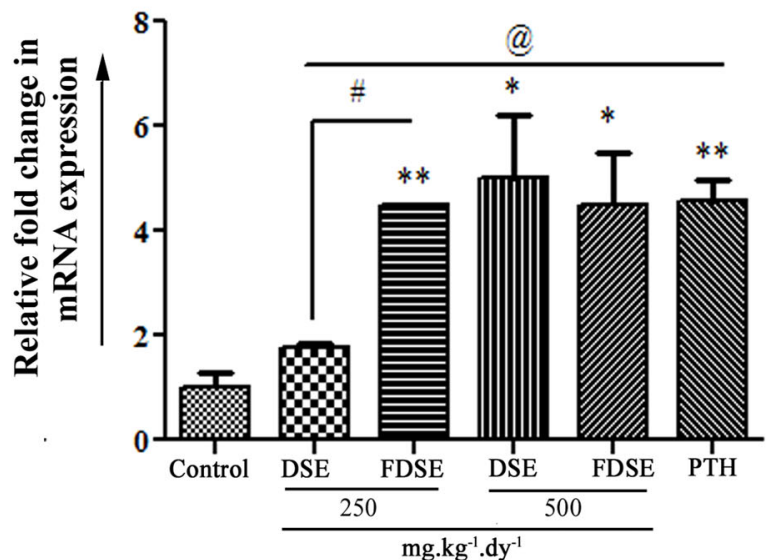

Fig. 3 a Representative confocal images (X100) of calcein labeling in the drill-hole site of various groups. $\mathbf{b}$ Data shows the quantification of the mean intensity of calcein labeling at the drill-hole site after treatment. Expression of osteogenic genes BMP2 (c), COL1 (d), BMP4 (e) quantitated by qPCR at fracture site. Values represent Mean \pm SEM $\left(n=10\right.$ rats/group). $p<0.05,{ }^{* *} p<0.01,{ }^{* * *} p<0.001$ compared with control. ${ }^{*} p<0.05,{ }^{\# \#} p<$ $0.01,{ }^{\# \#} p<0.001$ compared to formulated extract (FDSE) with corresponding dose of extract (DSE). ${ }^{@} p<0.05$, ${ }^{@} p<0.01$, ${ }^{@ @ ~} p<0.001$ compared to PTH 


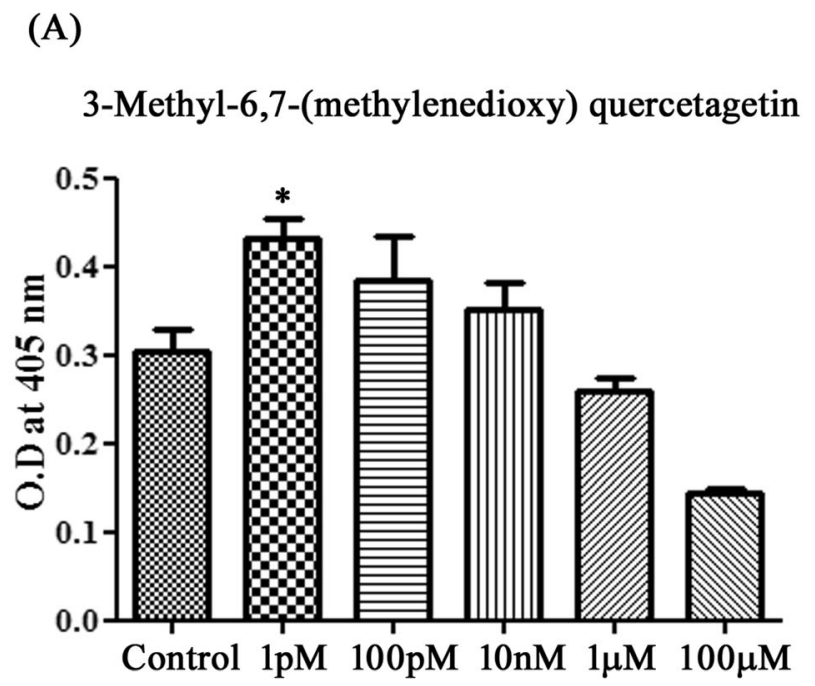

(C)

Pterospermin C

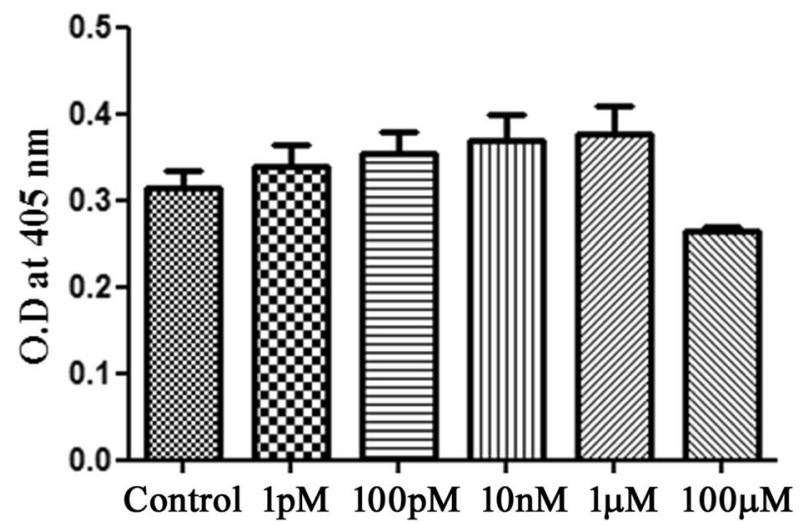

(B)

\section{3-O-methylpatuletin}

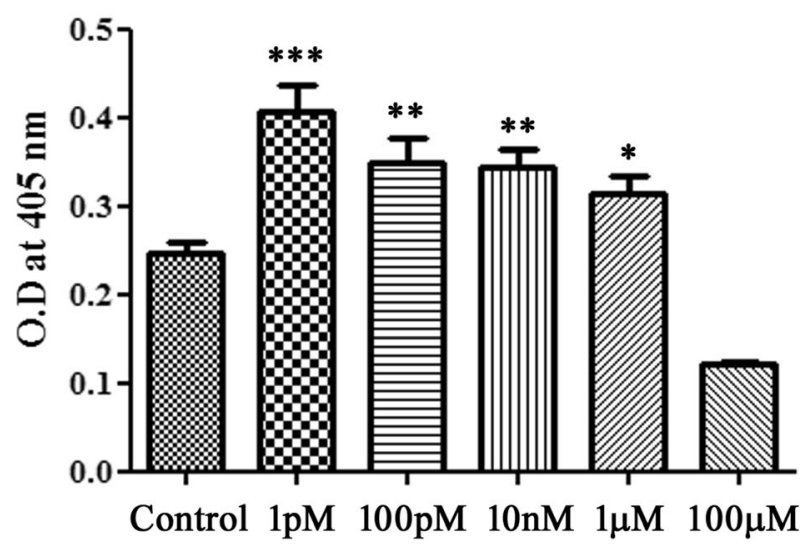

(D)

Adenosine

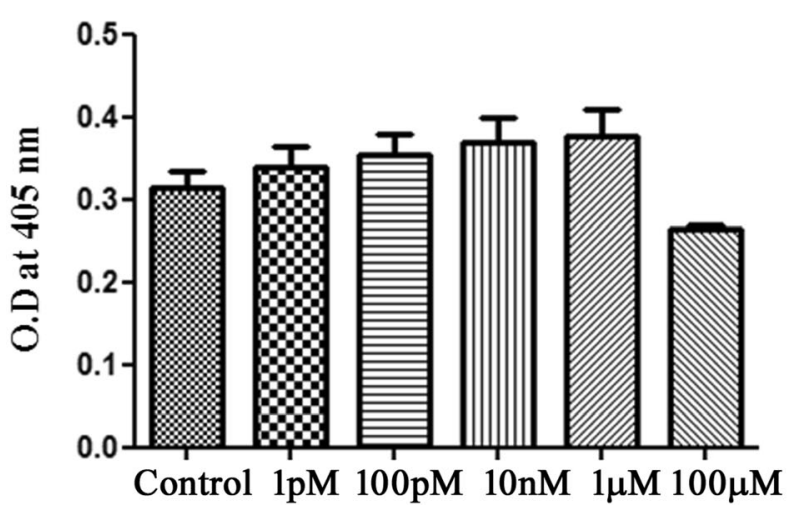

Fig. 4 Alkaline phosphatase (ALP) activity in calvarial osteoblast cells of isolated compounds from the extract. a 3-Methyl-6,7-(methylenedioxy) quercetagetin (K007) (b) 3-O-methylpatuletin (K008) (c) Pterospermin C (k009) (d) Adenosine (K010). Data shows Mean \pm S.E.M of three independent experiments ${ }^{* *} \mathrm{p}<0.001 ;{ }^{* *} \mathrm{p}<0.01$ and ${ }^{*} \mathrm{p}<0.05$ as compared with untreated cells taken as control

diminished by $20 \%$ (non-significant change) and 33\% $(p<0.001)$ in DSE and FDSE respectively (Fig. 2e). This further validated the affectivity of FDSE at 250 mg.kg-1 $\mathrm{dy}^{-1}$ (decreased Tb. Sp by $24 \%(p<0.05)$ compared to only DSE at the same dose). Additionally, SMI an important parameter of fracture healing was diminished by $43 \%(p<0.01)$ and $51 \%(p<0.001)$ at higher dose of DSE and FDSE respectively and $52.5 \%(p<$ 0.001) in PTH group. $250 \mathrm{mg} \cdot \mathrm{kg}^{-1} \mathrm{dy}^{-1}$ DSE exhibited a $27.2 \%(p<0.05)$ decrease against a sharp 60\% $(p<0.001)$ decline in FDSE at same dose relative to control group and $46.3 \%$ difference in comparison to DSE (Fig. 2f). Overall, the data showed that DSE at $500 \mathrm{mg} \cdot \mathrm{kg}^{-1} \mathrm{dy}^{-1}$ was effective in fracture healing and FDSE was effective in lowering the dose to half, thus validating that the SEDDS formulation enhanced the bone healing property of DSE apparently lowering its effective dose.
Effect of extract and formulation on callus formation at the fracture site

Figure 3a depicts representative confocal images of calcein labeling at fracture site. The intensity of calcein is proportional to mineralization of the callus at the fracture site. As evident from the images and intensity measurement DSE at doses $500 \mathrm{mg} \cdot \mathrm{kg}^{-1} \mathrm{dy}^{-1}$ showed an increment of $\sim 36.5 \%(p<0.01)$ compared to control (Fig. 3b). However, FDSE at both doses enhanced the intensity by $\sim 76 \%(p<0.001)$ compared to control. However maximum mineralization was observed in PTH treated group $(\sim 80 \%)(p<0.001)$ compared to control. These results clearly revealed that the extract was effective in callus formation at the fractured site which is proportional to new bone formation and FDSE at 250 mg. $\mathrm{kg}^{-1} \mathrm{dy}^{-1}$ dose showed significantly higher calcein intensity then corresponding DSE. 


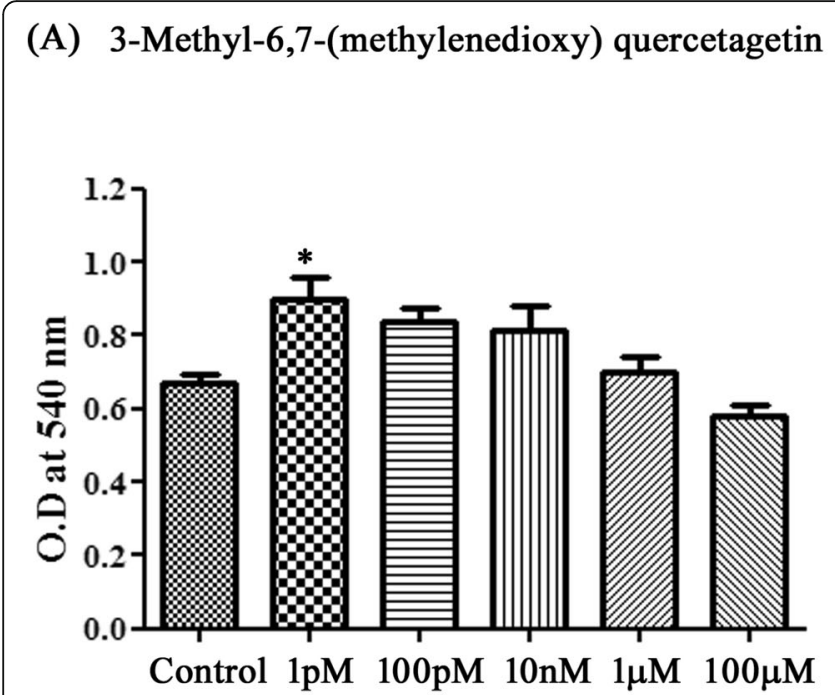

(B) 3-O-methylpatuletin

(C)

Pterospermin C

(D)

Adenosine
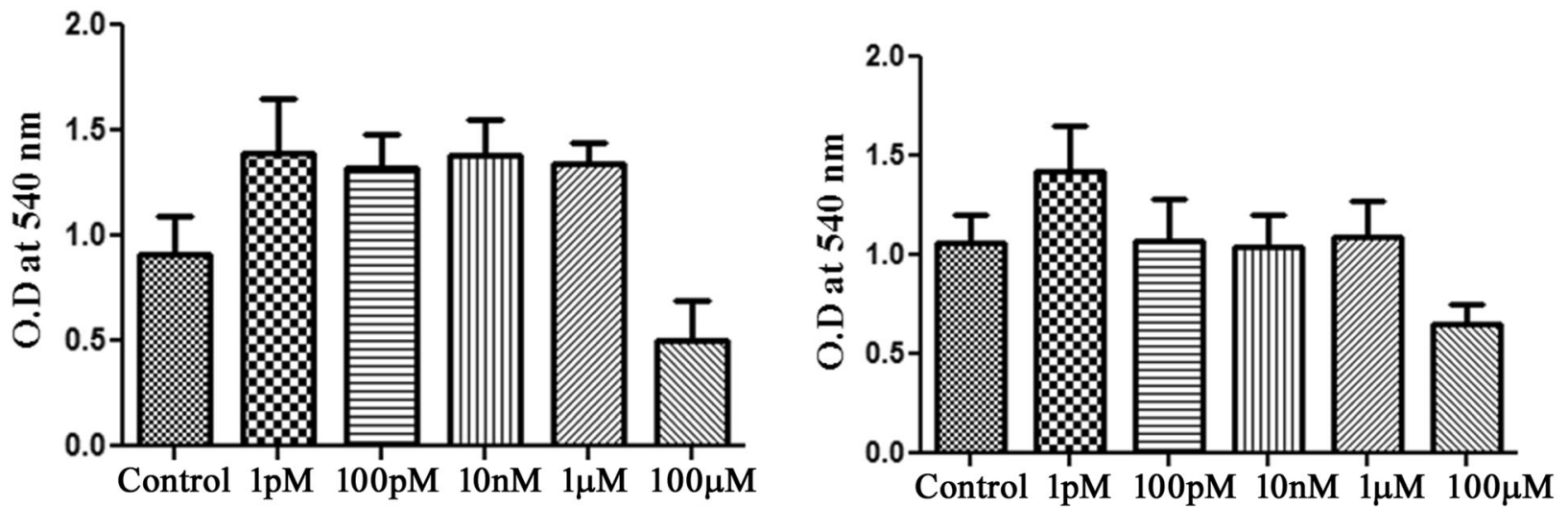

Fig. 5 MTT assay of isolated compounds depicting effect on cell viability. Cells were cultured in differentiation medium and treated with various concentrations of the compound ranging from $100 \mathrm{pM}$ to $1 \mathrm{mM}$ for. The percent viable cells were calculated as compared to untreated cells taken as control. a 3-Methyl-6,7-(methylenedioxy) quercetagetin (K007) (b) 3-O-methylpatuletin (K008) (c) Pterospermin C (k009) (d) Adenosine (K010). Data shows Mean \pm S.E.M of three independent experiments ${ }^{* *} p<0.001 ;{ }^{* *} p<0.01$ and ${ }^{*} p<0.05$ as compared with untreated cells taken as control

Effect of extract and formulation on osteogenic gene expression

The expression of osteogenic genes BMP-2, BMP-4, COL1 were assessed by real time quantitative PCR (Fig. 3c-e). The expression level of BMP-2 was up-regulated $\sim 2$ fold and $\sim 5$ fold for $250 \mathrm{mg} \cdot \mathrm{kg}^{-1} \mathrm{dy}^{-1}$ for DSE and FDSE respectively. However, for COL-1 the expression profile was different in DSE (no significant change) and FDSE $(\sim 4$ fold change) at lower dose, showing enhanced augmentation in FDSE. Whereas, at higher dose the similar increase in expression was observed for DSE, FDSE and PTH. Another important protein, BMP-4 is expressed in later stages of fracture repair was studied for various groups. The results revealed that BMP-4 expression was amplified by 4 fold in FDSE at both doses, whereas five fold in 500 mg. $\mathrm{kg}^{-1} \mathrm{dy}^{-1}$ DSE and PTH. Thus, the quantitative real time gene expression data exhibited the effective dose of DSE to be $500 \mathrm{mg} \cdot \mathrm{kg}^{-1} \mathrm{dy}^{-1}$ while the dose was reduced to half in FDSE treated animals.

Effect of isolated compounds on in vitro calvarial osteoblast cells

Screening of compounds using osteoblast differentiation and cell viability assay

The compounds isolated from extract (3-Methyl-6,7-(methylenedioxy) quercetagetin (K007), 3-O-methylpatuletin (K008), Pterospermin C (K009) and Adenosine (K010) were screened for alkaline phosphatase (ALP) activity, an important marker 
of osteoblast differentiation and cell toxicity study by MTT assay in primary rat calvarial osteoblasts. All the compounds screened, showed comparable ALP activity to vehicle treated cells (Fig. 4). K008 demonstrated 65.2\% $(p<0.001)$ increased ALP activity at $1 \mathrm{pM}$ and $40 \%(p<0.01)$ augmentation at $100 \mathrm{pM}$ and $10 \mathrm{nM}$ (Fig. 4b). Further data from MTT assay demonstrated that compound K008 was well tolerated at all concentration (resulted in 44\%; $p<0.001$ increased viability at $1 \mathrm{pM})$ and showed no inhibitory effect on cell proliferation (Fig. 5b). Overall the data suggested that $\mathrm{K} 008$ was active at all concentration with maximum activity at $1 \mathrm{pM}$ concentration and apparently one of the components for the enhanced in vivo activity of DSE. Additionally the $\mathrm{EC}_{50}$ (half maximal effective concentration) values of the compounds (Table 2) calculated from ALP assay demonstrated that K008 as the compound effective at lowest concentration.

\section{Mineralizing ability of screened compounds in calvarial osteoblast}

Representative images of alizarin stained cells (Fig. 6a) and quantification of data revealed that compound K008 augmented calcium nodule formation (Fig. 6b) in differentiated osteoblast by $\sim 60 \%$ at $1 \mathrm{pM}$ and $~ 30 \%$ at $10 \mathrm{nM}$ and $100 \mathrm{pM}$ concentration.

\section{Effect of active compound increased osteoblastogenesis related marker gene expression}

RUNX-2, a bone specific transcription factor and BMP-2 are key regulators of osteoblast differentiation exhibited $\sim 1.2$ and $\sim 2.5$ fold change at $1 \mathrm{pM}$ concentration of compound $\mathrm{K} 008$ for $48 \mathrm{~h}$ (Fig. 6c and d). ALP (Fig. 6e) and COL-1 (Fig. 6f) involved in the matrix maturation and mineralization was enhanced by $\sim 1.4$ and $\sim 1.5$ fold respectively at $1 \mathrm{pM}$. From the qPCR analysis it was evident that $\mathrm{K} 008$ was prolific in augmenting the process of differentiation and mineralization of osteoblast cells.
Effect of active compound on ROS generation stimulated by $\mathrm{H}_{2} \mathrm{O}_{2}$

ROS was increased as a result of treatment with $\mathrm{H}_{2} \mathrm{O}_{2}$ as evident from the increased fluorescence. Cells pretreated with $\mathrm{K} 008$ completely alleviated the $\mathrm{H}_{2} \mathrm{O}_{2}$ induced increased ROS generation as assessed by DCFDA. ROS was observed to be reduced in concentration gradient manner with compound K008 treatment as evident from O. D comparable to negative control NAC (Fig. 6g).

\section{Effect of extract and formulation on pharmacokinetic parameters}

LC-MS/MS method for quantitative estimation of the four biomarkers (K007, K008, K009 and K010) of Spinacia oleracea L. was developed. K007, K008, K009 and K010 were found to be present $0.20,0.013,0.0004$ and $0.046 \%$, respectively. The LC-MS/MS method applies to $50 \mu \mathrm{L}$ of serum and exhibited excellent linearity between 1 and 200 ng. $\mathrm{ml}^{-1}$. Recoveries of the markers was $>70 \%$ for K007 and K008 but < 5\% for K009 and K010 with acceptable accuracy and precision.

The animals tolerated the treatment as no peculiarities in the animal behavior were observed. The absorption of both $\mathrm{K} 007$ and $\mathrm{K} 008$ was rapid with peak serum concentration (Cmax) at $2 \mathrm{~h}$ and were monitored up to $8 \mathrm{~h}$ on oral administration of formulation (Table 3). The serum concentration-time profile obtained after oral administration of formulation was subjected to noncompartmental analysis and the calculated pharmacokinetic parameters are shown in Table 2 . The volume of distribution (K007, 43.3 L/kg; K008, $5.6 \mathrm{~L} / \mathrm{kg}$ ) is larger than the total blood volume of rat $(0.054 \mathrm{~L} / \mathrm{kg})$ [27] and systemic clearance (K007, $12.8 \mathrm{~L} / \mathrm{h} / \mathrm{kg}$ ) is also higher than the total hepatic blood flow in rats $(2.9 \mathrm{~L} / \mathrm{h} / \mathrm{kg})$ [27] indicating extravascular distribution along with the extra-hepatic elimination.

Table 2 Pharmacokinetic parameter of K007 and K008 after single oral dose of FDSE (250 mg.kg $\left.{ }^{-1}\right)$ in SD rats

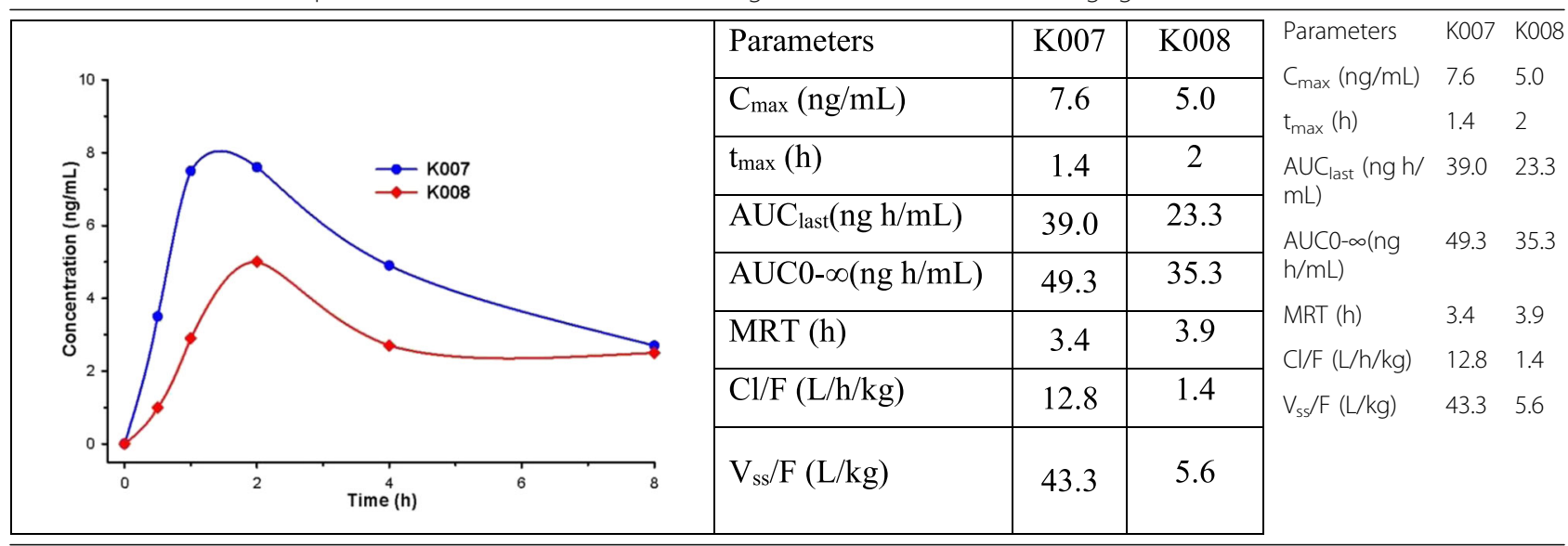

Abbreviations: $A \cup C_{\text {last }}=$ area under the serum concentration-time curve up to last observation, $C_{\max }=$ peak serum concentration, $t_{\text {max }}=$ time to $C_{\text {max }}, M R T=$ mean residence time, $V_{s s} / F=$ steady-state volume of distribution, $\mathrm{Cl} / \mathrm{F}=$ clearance, $\mathrm{F}=$ fraction of dose absorbed 
(A)

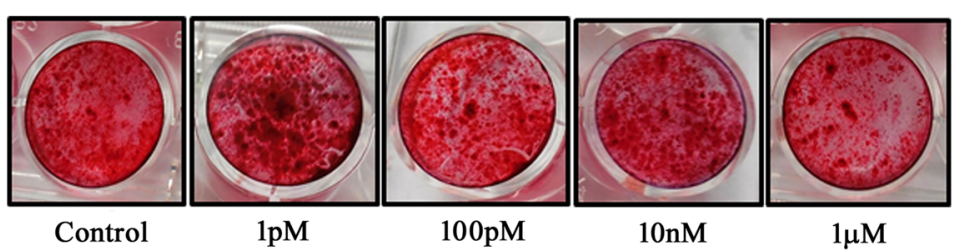

(B)

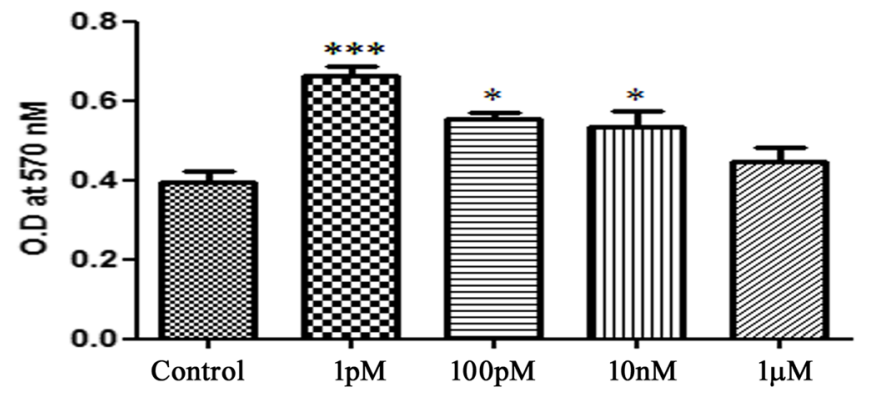

(C)

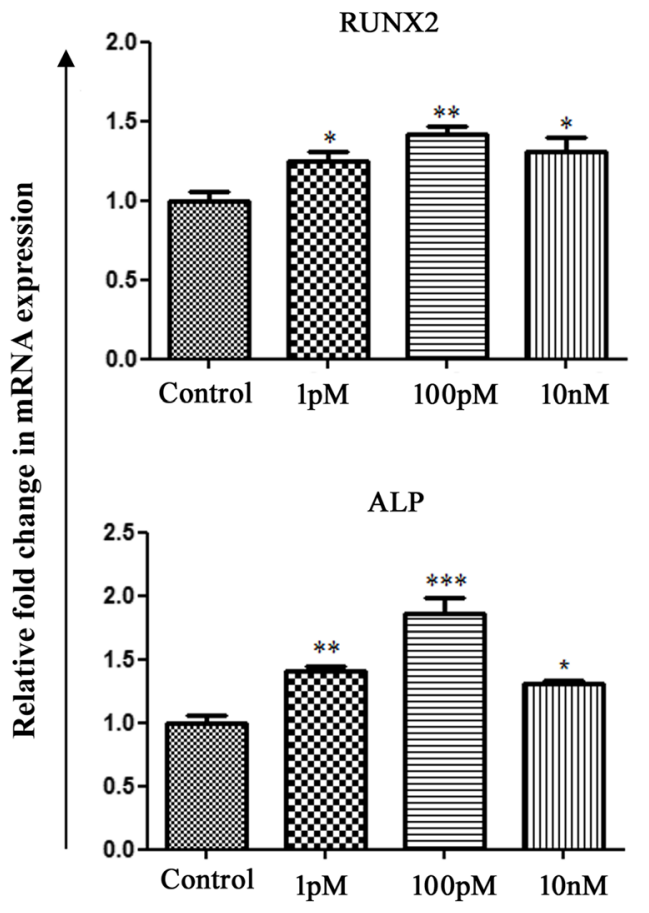

(D)

BMP2

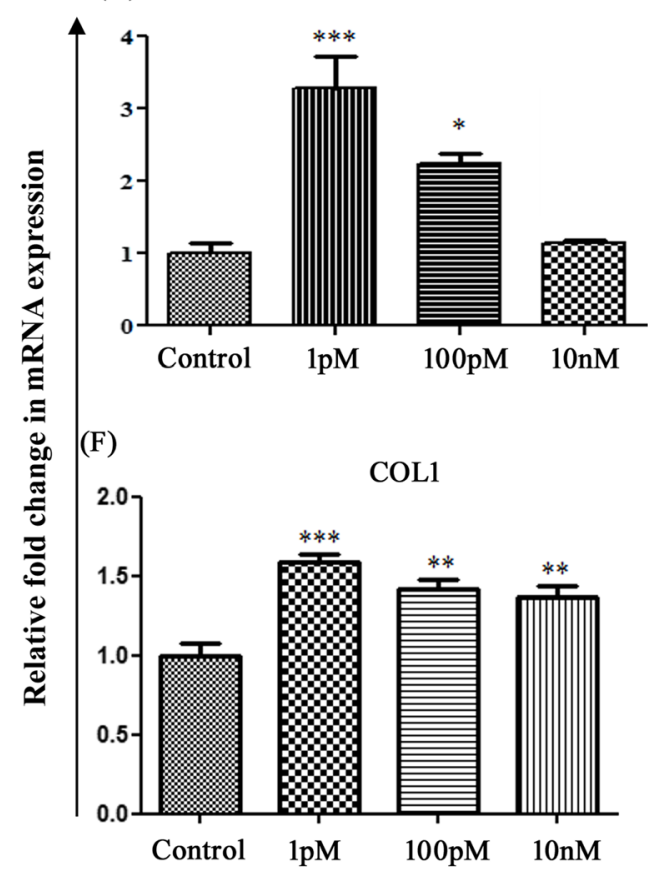

(G)

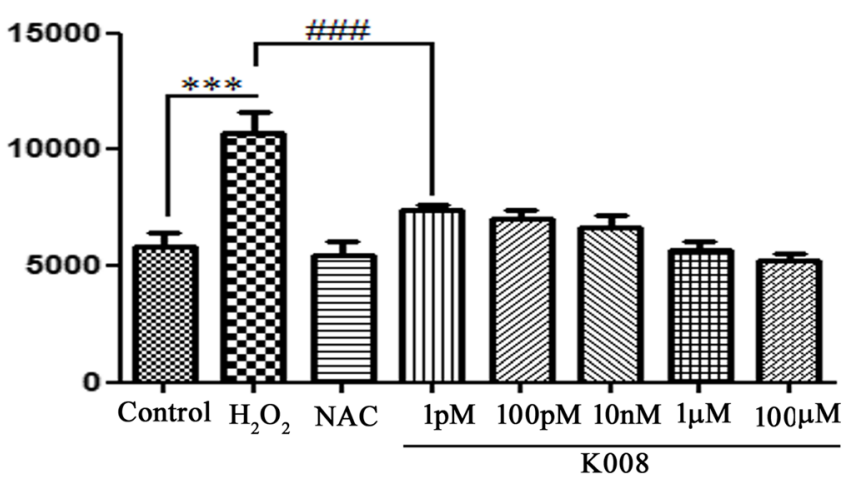

Fig. 6 (See legend on next page.) 
(See figure on previous page.)

Fig. 6 In vitro osteogenic and anti-ROS activity of the active compound 3-O-methylpatuletin (K008) in primary osteoblast cells. a-b Representative images of compound K008 treated Alizarin Red-S stained cells and quantification. Relative change in expression of osteogenic genes (c) RUNX2, (d) BMP2, (e) ALP, (f) COL1 in calvarial osteoblasts treated with compound K008 as compared to control by qPCR. ${ }^{*} p<0.05,{ }^{* *} p<0.01,{ }^{* * *} p<$ 0.001 compared with vehicle treated control cells. $\mathbf{g}$ Compound K008 inhibited ROS generation stimulated by H2O2in osteoblast cells as assessed by DCFDA assay. ${ }^{* * *} p<0.001$ compared to only untreated cells. \#\#\# $<0.001$ compared to $\mathrm{H} 2 \mathrm{O} 2$ treated cells

\section{Discussion}

The aim of this study was to compare the bone regenerating property of dried extract of Spinacia oleracea and its self emulsifying formulation. The process of fracture repair in the drill hole model of injury involves intramembranous ossification resulting in the formation of bone directly, without forming cartilage, from committed osteoprogenitor and undifferentiated mesenchymal cells that resides in the periosteum, and results in formation of hard callus [28-30]. Our study clearly indicated that the dried spinach extract (DSE) augmented the process of repair at the drill-hole by newly generated bone at a dose of $500 \mathrm{mg} \cdot \mathrm{kg}^{-1} \mathrm{dy}^{-1}$ as assessed by both dynamic (calcein labeling) and microarchitecture measurements. However, the effective dose was reduced to $250 \mathrm{mg} \cdot \mathrm{kg}^{-1} \mathrm{day}^{-1}$ in SEDDS formulated extract on the same animal model, attributed to increased bioavailability of the extract. The SEDDS formulation exhibited a $23 \%$ and $35 \%$ increase in BV/TV and Tb.N. at dose of $250 \mathrm{mg} \cdot \mathrm{kg}^{-1}$ day $^{-1}$ dose as compared to extract. SEDDS formulations are an important tool to increase the solubility of lipophilic drugs and offer the potential for enhancing drug absorption and oral bioavailability. The oleic acid and propylene glycol used in the SEDDS formulation here are Generally Regarded as Safe (GRAS) and all other components are approved for oral administration by the US FDA. The SEDDS formulation shows high loading i.e. $10 \% \mathrm{w} / \mathrm{w}$ and after dilution with water the nano-emulsion was spontaneously formed with no evidence of precipitation which confirms its stability against dilution.

Transcriptional analysis from fractured bone exhibited stimulation in expression osteogenic genes BMP-2, BMP-4 and COL-1 at the fracture site, markers for fracture healing. Bone morphogenetic proteins (BMPs) play an important role in cellular migration, differentiation, division, and matrix synthesis in the process of fracture healing. BMP-2 is an important factor facilitating the formation of new bone at fracture site during the process of healing. BMP-2 is expressed during the complete period of healing and initiates the expression of other important morphogenetic proteins [31]. BMP-2 expression was stimulated remarkably in animals with SEDDS formulated DSE at dose of $250 \mathrm{mg} \cdot \mathrm{kg}^{-1} \mathrm{day}^{-1}$ indicating robust and faster healing. BMP-4 is expressed during callus formation and enhances the osteo-inductive capacity of the mesenchymal cells to osteoblasts $[29,32]$. COL-1 represents the process of bone remodeling at the site of injury. Our results reveal up regulation in BMP-4 and COL-1 expression at comparatively lower dose of the formulation apparently indicating its efficacy in modulating the cellular mechanism of fracture repair. Formulation of extract resulted in lowering of particle size and increased solubility, therefore efficacy as is also evident from the increased calcein intensity thus establishing the fact that the formulation intensifies the process of bone regeneration at the fracture site at cellular level at a lower dose.

This increase in bone accretion at the drill hole appears to be attributed to the presence of flavonoids and bioactive compounds which increase the differentiation of calvarial osteoblast cells in in vitro. Further, isolation of bioactive constituents from the extract and assessing their osteogenic activity in vitro aided in validating the active biomarkers from the extract. Spinach has high flavonoid content. Thirty six compounds were identified based on their retention times, accurate mass and MS/ MS spectra [33], out of which four compounds 5, 3', 4' trihydroxy-3-methoxy-6,7-methylenedioxy-flavone (K007), 3-O-methylpatuletin (K008), Pterospermin C (K009) and Adenosine (K010) exhibited osteoblast differentiation as evident from ALP assay. K008 showed enhanced osteogenic differentiation at all concentration

Table 3 Compounds isolated from extract of Spinacia oleracea

\begin{tabular}{|c|c|c|c|c|}
\hline Code no. & Molecular formula & Molecular weight & Chemical Name & EC50 \\
\hline K007 & $\mathrm{C}_{17} \mathrm{H}_{12} \mathrm{O}_{8}$ & 344 & $\begin{array}{l}\text { 3-Methyl-6,7-(methylenedioxy) quercetagetin } \\
\text { or } \\
\text { 5, 3', 4'-trihydroxy-3-methoxy-6,7-methylenedioxy-flavone, }\end{array}$ & $5.9 \mu \mathrm{M}$ \\
\hline K008 & $\mathrm{C}_{17} \mathrm{H}_{14} \mathrm{O}_{8}$ & 346 & $\begin{array}{l}\text { 3-O-methylpatuletin } \\
\text { or } \\
5,7,3 \text { 3', 4'-tetrahydroxy-3,6-dimethoxy-flavone }\end{array}$ & $1.12 \mu \mathrm{M}$ \\
\hline K009 & $\mathrm{C}_{10} \mathrm{H}_{13} \mathrm{~N}_{5} \mathrm{O}_{4}$ & 267 & Pterospermin C & $7.56 \mu \mathrm{M}$ \\
\hline K010 & $\mathrm{C}_{4} \mathrm{H}_{4} \mathrm{O}_{4}$ & 116 & Adenosine & $1.32 \mu \mathrm{M}$ \\
\hline
\end{tabular}


attributed to low cell cytotoxicity evident from the MTT assay. Further, K008 exhibited maximum up-regulation in the expression of RUNX-2, BMP-2, COL-1 and ALP compared to untreated calvarial osteoblast cells. RUNX2 , a key transcription factor associated with osteoblast differentiation and its stimulation leads to osteoblast formation. BMP-2 is a marker of osteoblast differentiation is known to stimulate bone formation. COL-1 is well known to be involved in the matrix maturation and mineralization process. Alizarin staining revealed the affectivity of $\mathrm{K008}$ in increasing deposition of calcium nodules in differentiated osteoblast cells.

When bone fracture occurs, a remarkable yield of free radicals is generated by the damaged tissues thus elevating the reactive oxygen species at injured site [34]. Any exogenous agent to aid in bone healing should have the capacity to form either osteoblast or cartilage from undifferentiated mesenchymal cells along with antioxidant and anti-inflammatory property. Phytochemicals with anti-oxidative capacity (such as kaempferol, quercetin) present in spinach regulate bone metabolism by reducing the production of (ROS) reactive oxygen species and by improving anti-oxidative capacity $[6,35,36]$. Moreover, 3-O-methylpatuletin, one of the biomarker isolated from the extract demonstrated ROS scavenging activity induced by $\mathrm{H}_{2} \mathrm{O}_{2}$ in osteoblast cells.

The pharmacokinetics of extract and its formulation detected all the four markers (K007, K008, K009 and K010) in serum samples below LLOQ $(1 \mathrm{ng} / \mathrm{mL})$. Following enzymatic hydrolysis of the serum samples, only K007 and K008 could be quantified up to $8 \mathrm{~h}$ in the hydrolyzed serum samples of the rats treated with the formulation. They exhibited low systemic availability, large volume of distribution, high clearance and mean residence time of $\sim 3.5 \mathrm{~h}$.

\section{Conclusion}

Collectively, our findings suggest that the SEDDS formulation facilitated to improve the absorption and bioavailability of biomarkers that resulted in improved efficacy at almost half dose of extract. It accelerated fracture repair and by increasing the production of osteoprogenitor cells and their differentiation to osteogenic lineage thereby enhancing the recruitment of osteoblast to the injury site as well as stimulating the ability of the cells to produce osteogenic cytokine, BMP-2 and deposition of matrix protein, COL-1, ultimately accelerate fracture healing.

\section{Supplementary information}

Supplementary information accompanies this paper at https://doi.org/10. 1186/s40816-020-00190-z.

\section{Additional file 1.}

\section{Abbreviations}

MIA: monosodium iodoacetate; SEDDS: self-emulsifying drug delivery system; PTH: para-thyroid hormone; BMPs: bone morphogenetic proteins; DSE: dried spinach extract; FDSE: formulated dried spinach extract; a-MEM: alphaModified Eagle Medium; FBS: Fetal bovine serum; 3-MTT: (4,5dimethylthiazol-2-yl)-2,5-diphenyltetrazolium bromide; DCFDA: 2',7'Dichlorofluorescindi- acetate (DCFDA); $\mu-C T$ : micro-Computed tomography; AUC: area under curve; $\left(C_{\text {max }}\right)$ : peak serum concentration; $C_{\max }\left(t_{\max }\right)$ : time to $C_{\text {maxi }}$ Cl: total clearance; MRT: mean residence time; $\left(V_{s s}\right)$ : steady state volume distribution; RCO: Rat calvarial osteoblast; ALP: Alkaline phosphatase; DMSO: Dimethyl sulphoxide; pNPP: para-nitrophenyl phosphate; qPCR: quantitative realtime polymerase chain reaction; ROS: reactive oxygen species; $\mathrm{H}_{2} \mathrm{O}_{2}$ : hydrogen peroxide; NAC: N-acetyl-L-cysteine; K007: 3-Methyl6,7-(methylenedioxy) quercetagetin; K008: 3-O-methylpatuletin; K009: Pterospermin C; K010: Adenosine; $\mathrm{EC}_{50}$ : half maximal effective concentration; BV/TV: bone volume/tissue volume; Tb.N: trabecular number; Tb.Sp: trabecular separation; SMI: structural model index; BMP-2: bone morphogenetic protein-2; BMP-4: bone morphogenetic protein-4; RUNX2: runt related transcription factor 2; COL-1: Collagen I

\section{Acknowledgments}

We gratefully acknowledge the University Grant Commission (UGC), Council of Scientific and Industrial Research (CSIR) (New Delhi, India), for the award of research fellowships. We also acknowledge the financial support of CSIR, Indian Council of Medical Research. We acknowledge Dr. Kavita Singh of electron microscope unit of CSIR-CDRI for collecting images of confocal microscopy data reported in this article and Dr. Kalyan Mitra for facilitating confocal imaging.

\section{Authors' contributions}

SA, PK, NA carried out the animal experiments and in vitro cell culture work. NM, GP made the formulation under the supervision of PRM. MS carried out the pharmacokinetics study under the supervision of JL. SK carried out the plant extraction and characterization of isolated compounds under the supervision of RM. DC assisted in gene expression studies. Manuscript draft was prepared by SA and DC. PRM and RT supervised the work and finalized the manuscript. All authors have read and approved the manuscript.

\section{Funding}

University Grant Commission (UGC), Council of Scientific and Industrial Research (CSIR), New approaches towards understanding dynamics and to accelerate drug discovery (UNDO-BSC0103), Indian Council of Medical Research (ICMR-GAP0158), Government of India.

Availability of data and materials

The datasets analyzed during the current study are available from the corresponding author on request.

Ethics approval and consent to participate

All experiments were carried out according to the guidelines for care and use of experimental animals and approved by the Institutional Animal Ethical Committee, (IAEC) (IAEC/2014/38] at C.D.R.I.

Consent for publication

Not applicable.

\section{Competing interests}

The authors declare no competing interests.

\section{Author details}

'Division of Endocrinology, CSIR-Central Drug Research Institute, B.S. 10/1, Sector 10, Jankipuram Extension, Sitapur Road, Lucknow, Uttar Pradesh 226031, India. ${ }^{2}$ Division of Pharmaceutics, CSIR-Central Drug Research Institute, B.S. 10/1, Sector 10, Jankipuram Extension, Sitapur Road, Lucknow, Uttar Pradesh 226031, India. ${ }^{3}$ Division of Pharmacokinetics, CSIR-Central Drug Research Institute, B.S. 10/1, Sector 10, Jankipuram Extension, Sitapur Road, Lucknow, Uttar Pradesh 226031, India. ${ }^{4}$ Division of Medicinal and Process Chemistry, CSIR-Central Drug Research Institute, CSIR-Central Drug Research Institute, B.S. 10/1, Sector 10, Jankipuram Extension, Sitapur Road, Lucknow, Uttar Pradesh 226031, India. 
Received: 24 September 2019 Accepted: 3 July 2020

Published online: 24 July 2020

\section{References}

1. Lomnitski L, Bergman M, Nyska A, Ben-Shaul V, Grossman S. Composition, efficacy, and safety of spinach extracts. Nutr Cancer. 2003:46(2):222-31. https://doi.org/10.1207/S15327914NC4602_16.

2. Lomnitski L, Foley JE, Grossman S, Shaul VB, Maronpot RR, Moomaw CR, Carbonatto M, Nyska A. Effects of apocynin and natural antioxidant from spinach on inducible nitric oxide synthase and cyclooxygenase-2 induction in lipopolysaccharide-induced hepatic injury in rat. Pharmacol Toxicol. 2000;87(1):18-25.

3. Nyska A, Suttie A, Bakshi S, Lomnitski L, Grossman S, Bergman M, Ben-Shaul V, Crocket P, Haseman JK, Moser G, Goldsworthy TL, Maronpot RR. Slowing tumorigenic progression in TRAMP mice and prostatic carcinoma cell lines using natural anti-oxidant from spinach, NAO--a comparative study of three anti-oxidants. Toxicol Pathol. 2003;31(1):39-51. https://doi.org/10.1080/ 01926230390173833.

4. Abd Jalil MA, Shuid AN, Muhammad N. Role of medicinal plants and natural products on osteoporotic fracture healing. Evid Based Complement Alternat Med. 2012;2012:714512. https://doi.org/10.1155/2012/714512.

5. Adhikary S, Choudhary D, Ahmad N, Kumar S, Dev K, Mittapelly N, Pandey G, Mishra PR, Maurya R, Trivedi R. Dried and free flowing granules of Spinacia oleracea accelerate bone regeneration and alleviate postmenopausal osteoporosis. Menopause. 2017;24(6):686-98. https://doi. org/10.1097/GME.0000000000000809.

6. Choudhary D, Kothari P, Tripathi AK, Singh S, Adhikary S, Ahmad N, Kumar S, Dev K, Mishra VK, Shukla S, Maurya R, Mishra PR, Trivedi R. Spinacia oleracea extract attenuates disease progression and sub-chondral bone changes in monosodium iodoacetate-induced osteoarthritis in rats. BMC Complement Altern Med. 2018;18(1):69. https://doi.org/10.1186/s12906-018-2117-9.

7. Marsell R, Einhorn TA. The biology of fracture healing. Injury. 2011;42(6):5515. https://doi.org/10.1016/j.injury.2011.03.031

8. Thilakarathna SH, Rupasinghe HP, Needs PW. Apple peel bioactive rich extracts effectively inhibit in vitro human LDL cholesterol oxidation. Food Chem. 2013;138(1):463-70. https://doi.org/10.1016/j.foodchem.2012.09.121.

9. Scheline RR. Metabolism of foreign compounds by gastrointestinal microorganisms. Pharmacol Rev. 1973;25(4):451-523.

10. Manach C, Williamson G, Morand C, Scalbert A, Remesy C. Bioavailability and bioefficacy of polyphenols in humans. I. Review of 97 bioavailability studies. Am J Clin Nutr. 2005;81(1 Suppl):230S-42S. https://doi.org/10.1093/ ajen/81.1.230s.

11. Mullen W, Edwards CA, Crozier A. Absorption, excretion and metabolite profiling of methyl-, glucuronyl-, glucosyl- and sulpho-conjugates of quercetin in human plasma and urine after ingestion of onions. $\mathrm{Br} J$ Nutr. 2006;96(1):107-16. https://doi.org/10.1079/bjn20061809.

12. Rupasinghe HP, Ronalds CM, Rathgeber B, Robinson RA. Absorption and tissue distribution of dietary quercetin and quercetin glycosides of apple skin in broiler chickens. J Sci Food Agric. 2010;90(7):1172-8. https://doi.org/ 10.1002/jsfa.3944.

13. Dwivedi P, Khatik R, Khandelwal K, Srivastava R, Taneja I, Rama Raju KS, Dwivedi H, Shukla P, Gupta P, Singh S, Tripathi R, Paliwal SK, Wahajuddin DAK, Mishra PR. Self-nanoemulsifying drug delivery systems (SNEDDS) for oral delivery of arteether: pharmacokinetics, toxicity and antimalarial activity in mice. RSC Adv. 2014;4(110):64905-18. https://doi.org/10.1039/ C4RA09267H.

14. Arya A, Ahmad H, Tulsankar S, Agrawal S, Mittapelly N, Boda R, Bhatta RS, Mitra K, Dwivedi AK. Bioflavonoid hesperetin overcome bicalutamide induced toxicity by co-delivery in novel SNEDDS formulations: optimization, in vivo evaluation and uptake mechanism. Materials Sci Eng. 2017;C 71:95464. https://doi.org/10.1016/j.msec.2016.11.006.

15. Bi X, Liu X, Di L, Zu Q. Improved Oral bioavailability using a solid selfmicroemulsifying drug delivery system containing a multicomponent mixture extracted from Salvia miltiorrhiza. Molecules (Basel, Switzerland). 2016;21(4):456. https://doi.org/10.3390/molecules21040456.

16. Tsiridis E, Upadhyay N, Giannoudis P. Molecular aspects of fracture healing: which are the important molecules? Injury. 2007:38(Suppl 1):S11-25. https:// doi.org/10.1016/j.injury.2007.02.006.

17. Einhorn TA, Gerstenfeld LC. Fracture healing: mechanisms and interventions. Nat Rev Rheumatol. 2015;11(1):45-54. https://doi.org/10. 1038/nrrheum.2014.164
18. McKibbin B. The biology of fracture healing in long bones. J Bone Joint Surg Br. 1978;60-B(2):150-62.

19. Prendergast PJ, Huiskes R, Soballe K. ESB Research Award 1996. Biophysical stimuli on cells during tissue differentiation at implant interfaces. J Biomech. 1997;30(6):539-48

20. Klontzas ME, Kenanidis El, MacFarlane RJ, Michail T, Potoupnis ME, Heliotis M, Mantalaris A, Tsiridis E. Investigational drugs for fracture healing: preclinical \& clinical data. Expert Opin Investig Drugs. 2016;25(5):585-96. https://doi.org/10.1517/13543784.2016.1161757.

21. Dawson-Hughes B, Mithal A, Bonjour JP, Boonen S, Burckhardt P, Fuleihan GE, Josse RG, Lips P, Morales-Torres J, Yoshimura N. IOF position statement: vitamin D recommendations for older adults. Osteoporos Int. 2010;21(7): 1151-4. https://doi.org/10.1007/s00198-010-1285-3.

22. Nurmi-Luthje I, Luthje $P$, Kaukonen JP, Kataja M, Kuurne S, Naboulsi H, Karjalainen K. Post-fracture prescribed calcium and vitamin D supplements alone or, in females, with concomitant anti-osteoporotic drugs is associated with lower mortality in elderly hip fracture patients: a prospective analysis. Drugs Aging. 2009;26(5):409-21. https://doi.org/10.2165/00002512200926050-00005.

23. Lane NE, Thompson JM, Strewler GJ, Kinney JH. Intermittent treatment with human parathyroid hormone (hPTH[1-34]) increased trabecular bone volume but not connectivity in osteopenic rats. J Bone Miner Res. 1995; 10(10):1470-7. https://doi.org/10.1002/jbmr.5650101007.

24. Ke HZ, Crawford DT, Qi H, Simmons HA, Owen TA, Paralkar VM, Li M, Lu B, Grasser WA, Cameron KO, Lefker BA, DaSilva-Jardine P, Scott DO, Zhang Q, Tian XY, Jee WS, Brown TA, Thompson DD. A nonprostanoid EP4 receptor selective prostaglandin E2 agonist restores bone mass and strength in aged, ovariectomized rats. J Bone Miner Res. 2006;21(4):565-75. https://doi.org/10.1359/jbmr.051110.

25. Gupta S, Adhikary S, Modukuri RK, Choudhary D, Trivedi R, Sashidhara KV. Benzofuran-pyran hybrids: a new class of potential bone anabolic agents. Bioorg Med Chem Lett. 2018;28(10):1719-24. https://doi.org/10.1016/j.bmcl.2018.04.041.

26. Yu BW, Li JL, Guo BB, Fan HM, Zhao WM, Wang HY. Chlorogenic acid analogues from Gynura nepalensis protect $\mathrm{H} 9 \mathrm{c} 2$ cardiomyoblasts against H2O2-induced apoptosis. Acta Pharmacol Sin. 2016;37(11):1413-22. https:// doi.org/10.1038/aps.2016.79.

27. Davies B, Morris T. Physiological parameters in laboratory animals and humans. Pharm Res. 1993:10(7):1093-5.

28. Einhorn TA (1998) The cell and molecular biology of fracture healing. Clin Orthop Relat Res (355 Suppl):S7-21.

29. Dimitriou R, Tsiridis E, Giannoudis PV. Current concepts of molecular aspects of bone healing. Injury. 2005;36(12):1392-404. https://doi.org/10.1016/j. injury.2005.07.019.

30. Tanaka K, Tanaka S, Sakai A, Ninomiya T, Arai Y, Nakamura T. Deficiency of vitamin a delays bone healing process in association with reduced BMP2 expression after drill-hole injury in mice. Bone. 2010;47(6):1006-12. https:// doi.org/10.1016/j.bone.2010.08.016.

31. Ai-Aql ZS, Alagl AS, Graves DT, Gerstenfeld LC, Einhorn TA. Molecular mechanisms controlling bone formation during fracture healing and distraction osteogenesis. J Dent Res. 2008;87(2):107-18. https://doi.org/10. $1177 / 154405910808700215$.

32. Cheng H, Jiang W, Phillips FM, Haydon RC, Peng Y, Zhou L, Luu HH, An N, Breyer B, Vanichakarn P, Szatkowski JP, Park JY, He TC. Osteogenic activity of the fourteen types of human bone morphogenetic proteins (BMPs). J Bone Joint Surg Am. 2003;85-A(8):1544-52.

33. Singh A, Singh $P$, Kumar B, Kumar S, Dev K, Maurya R. Detection of flavonoids from Spinacia oleracea leaves using HPLC-ESI-QTOF-MS/MS and UPLC-QqQLIT-MS/MS techniques. Nat Prod Res. 2018:1-4. https://doi.org/10. 1080/14786419.2018.1489395.

34. Sheweita SA, Khoshhal KI. Calcium metabolism and oxidative stress in bone fractures: role of antioxidants. Curr Drug Metab. 2007:8(5):519-25.

35. Forte L, Torricelli P, Boanini E, Gazzano M, Rubini K, Fini M, Bigi A. Antioxidant and bone repair properties of quercetin-functionalized hydroxyapatite: An in vitro osteoblast-osteoclast-endothelial cell co-culture study. Acta Biomater. 2016:32:298-308. https://doi.org/10.1016/j.actbio.2015.12.013.

36. Weaver CM, Alekel DL, Ward WE, Ronis MJ. Flavonoid intake and bone health. J Nutr Gerontol Geriatr. 2012;31(3):239-53. https://doi.org/10.1080/ 21551197.2012.698220

\section{Publisher's Note}

Springer Nature remains neutral with regard to jurisdictional claims in published maps and institutional affiliations. 